\title{
Current Status Analysis and Suggestions Regarding Pollution Prevention and Control of Medical Wastes in Chongqing
}

\author{
Shuiwen Yang ${ }^{1, a^{*}}$, Manli Zhang, ${ }^{1, b}$, Qiang Liu ${ }^{1, c}$ and Jialie Liu ${ }^{1, d}$ \\ ${ }^{1}$ Chongqing Solid Waste Management Center, 401147, China \\ a*yangshuiwen@126.com, ${ }^{\mathrm{b}}$ 32310231@qq.com, \\ c50474783@qq.com, d624440350@qq.com
}

\begin{abstract}
Keywords: Medical wastes; Pollution prevention and control; Standardized management; Status analysis
\end{abstract}

\begin{abstract}
Objective: The purpose of this study is to point out existing problems of pollution prevention and control of medical wastes in Chongqing. Methods: The current status pollution prevention and control of medical wastes for 5 consecutive years (2011-2015) in Chongqing were analysized. Results: Furthermore, targeting the requirements of pollution prevention and control of medical wastes and environmental management in Chongqing, suggestions regarding the standardized management of medical wastes are proposed from the perspectives of perfecting the charging system of medical wastes, standardizing separate collections of medical wastes, establishing a medical waste information management system, and optimizing pollution prevention and control of medical wastes. Conclusion: These provide a reference for pollution prevention and control of medical wastes and environmental management in Chongqing and other regions.
\end{abstract}

\section{Introduction}

Medical wastes refer to direct or indirect infectious, toxic and other hazardous wastes produced by medical and health institutions in medical treatment, prevention, health care, and other related activities. Medical wastes are mainly classifed into infectious waste, pathological waste, damaging waste, drug-induced waste and chemical waste. In recent years, the output of medical wastes in Chongqing has reached 16,500 tons [1-3], resulting in an increasingly growing risk of disease transmission of medical wastes and environmental pollution. Therefore, it is especially important to strengthen medical waste pollution prevention and control and environmental management.

For the past several years, the Chongqing Municipal Government has continued to intensify efforts to prevent and control medical waste pollution, the construction speed of collection and concentrated disposal facilties of medical wastes accelerates year by year, and the concentrated collection scope of medical wastes is enlarged year by year [3]. However, while environmental protection requirements in Chongqing are improved and detailed, the output of medical wastes increases year by year, and concentrated disposal facilites and technolgies of medical wastes alter [3-4], thus the accumulated existing problems of pollution prevention and control of medical wastes over the years are gradually highlighted and exposed. Examples include the lack of reasonable charging system of medical wastes, the non-standard collection of medical wastes, and the shortage of information means on management of medical wastes [5]. At the same time, new problems such as requirements on pollution prevention and control of medical wastes not matching the concentrated disposal technologies change also appear. What we must consider and urgently resolve are the new and old problems existing in pollution prevention and control of medical wastes.

In this paper, new and old problems of pollution prevention and control of medical wastes are pointed out by analyzing the production, collection and disposal status of medical wastes in Chongqing, and suggestions regarding the standardized management of medical wastes are put forward, which provides a reference for pollution prevention and control of medical wastes in Chongqing and other regions. 


\section{Current Status of Pollution Prevention and Control of Medical Wastes}

Based on the production, collection, transfer and disposal of medical wastes, survey results on the current status of pollution prevention and control of medical wastes in Chongqing showed that in 2015 there were 19,807 medical and health institutions in Chongqing, producing 16,482 tons of medical wastes, including 16,288 tons of concentrated disposal, which accounted for $98.8 \%$ of the total disposal amount, and 194 tons of self-harmless disposal [1-3]. The concentrated disposal method of medical wastes is high-temperature steam treatment, while high-temperature incineration is only regarded as an emergency or standby method, and the self-harmless disposal method is the disinfection-destruction landfill method. See Table 1 for pollution prevention and control of medical wastes during 2011-2015 in Chongqing [1-3].

As can be seen from Table 1, the status of pollution prevention and control of medical wastes in Chongqing for the 5 consecutive years of 2011 to 2015 is characterized as follows:

The output of medical wastes in Chongqing increased by 7,871 tons from 8,611 tons in 2011 to 16,482 tons in 2015; however, in terms of annual growth rate, the growth rate is basically stable.

The concentrated collection and disposal amount of medical wastes in Chongqing increased by 16,288 tons in 2015 from 7,209 tons in 2011, while the self-harmless disposal amount decreased by 195 tons from 1,402. Such an "increase-decrease" indicates that the number of medical and health institutions throughout the city included in the concentrated collection is increasing year by year, and the concentrated collection scope is enlarged year by year. This is related to the fact that Chongqing attaches great importance to pollution prevention and control of medical wastes, and has intensified environmental supervision in recent years.

The concentrated disposal capacity of medical wastes in Chongqing continously increases. Concentrated disposal facilities have increased in number to 10 in 2015 from 4 in 2011, and the disposal capacity increased to 59.5 tons/day from 42 tons/day. However, the concentrated disposal method gradually changed to high-temperature steam sterilization from high-temperature incineration treatment, and was finally replaced by high-temperature steam sterilization, while the concentrated disposal capability increased year by year. Changes in this disposal method indicate that the concentrated collection and disposal methods of medical wastes in Chongqing are progresesively optimized. The high temperature steam sterilization method is more suitable for the high mountainous region in Chongqing with dispersed medical and health institutions, small output of medical wastes and wide scope, which greatly reduces the construction threshold of concentrated disposal facilities of medical wastes, and is more beneficial to the concentrated collection and disposal of medical wastes in the remote mountainous region of Chongqing.

As seen from the above characteristics, although medical wastes in Chongqing are collected and disposed harmlessly, it can be found that a portion of medical and health institutions are not included in the concentrated collection scope, and the self-harmless disposal of medical wastes still exists. Concentrated disposal methods of medical wastes have all been replaced by the high-temperature steam sterilization method. Consequently, analyzing and resolving the problems existing in the process of collection, transporation and disposal of medical wastes in Chongqing will be the key point and main difficulty in the pollution prevention and control of medical wastes in the next few years. The analysis of existing problems of pollution prevention and control of medical wastes in Chongqing at present is as follows. 
Table 1 Status of pollution prevention and control of medical wastes during 2011-2015 in Chongqing

\begin{tabular}{|c|c|c|c|c|c|c|c|}
\hline $\begin{array}{c}\text { Yea } \\
\mathrm{r}\end{array}$ & $\begin{array}{l}\text { Total number } \\
\text { of medical } \\
\text { and health } \\
\text { institutions }\end{array}$ & $\begin{array}{l}\text { Outpu } \\
\mathrm{t} \text { (ton) }\end{array}$ & $\begin{array}{c}\text { Concentrat } \\
\text { ed } \\
\text { disposal } \\
\text { amount } \\
\text { (tons) }\end{array}$ & $\begin{array}{c}\text { Self-harmle } \\
\text { ss disposal } \\
\text { amount } \\
\text { (tons) }\end{array}$ & $\begin{array}{c}\text { Harmless } \\
\text { disposal }\end{array}$ & $\begin{array}{c}\text { NO. of } \\
\text { centraliz } \\
\text { ed } \\
\text { disposal } \\
\text { facilities }\end{array}$ & $\begin{array}{c}\text { Concentrat } \\
\text { ed disposal } \\
\text { capability } \\
\text { (tons/day }\end{array}$ \\
\hline $\begin{array}{c}201 \\
1\end{array}$ & 17660 & 8611 & 7209 & 1402 & $\begin{array}{l}\text { High-temperatu } \\
\text { re incineration, } \\
\text { high-temperatur } \\
\text { e steam, } \\
\text { disinfection-des } \\
\text { truction landfill } \\
\text { method }\end{array}$ & 4 & 42 \\
\hline $\begin{array}{c}201 \\
2\end{array}$ & 17961 & 10360 & 9204 & 1156 & & 4 & 41 \\
\hline $\begin{array}{c}201 \\
3\end{array}$ & 18926 & 11307 & 10907 & 400 & $\begin{array}{l}\text { High-temperatu } \\
\text { re steam, } \\
\text { disinfection-des }\end{array}$ & 7 & 48.5 \\
\hline $\begin{array}{c}201 \\
4\end{array}$ & 18766 & 12507 & 12325 & 182 & truction landfill & 8 & 53.5 \\
\hline $\begin{array}{c}201 \\
5\end{array}$ & 19807 & 16482 & 16288 & 194 & & 10 & 59.5 \\
\hline
\end{tabular}

\section{Existing Problems}

The Urgent Improvement of Standardized Collection of Medical Waste must be Improved. First, the collection of medical waste lacks standardization, which causes great difficulties and harm to the transfer and disposal of medical wastes [5]. For example, the mixed collection of medical and domestic wastes; ordinary domestic garbage bags containing medical wastes; and damaged waste contained in paper or plastic bags. Second, medical institutions are scattered in remote areas and far away from disposal units. In addition, medical wastes are characterized by small production amount and high concentrated collection cost, and are often stored for extended periods, which greatly increases the risk of disease transmission [6].

The lack of Informatization means in the Management of Medical Waste Environment. First, paper duplicate management is still used for the transfer of medical wastes. Paper duplicate has many shortcomings, such as difficult count of medical wastes, optional filling in quantity, and distribution lag of paper duplicates, which make it difficult to meet the requirements of environmental management informationization. Second, the Environmental Protection Departments at different levels report and summarize the production, transfer and disposal information artificially without using informatization management means of medical wastes. This makes it impossible to realize summarized analyses of large amounts of data, and is not compatible with the current internet management requirements of solid waste.

The Requirements of Pollution Prevention and Control of Medical Waste does not Match with the Centralized Treatment Technological Change of Medical Wastes. First, although the concentrated disposal technology of medical waste in Chongqing has been changed to high-temperature steam sterilization, which can adapt relatively well to the generation characteristics of medical waste and its disposal requirements in the mountainous regions of Chongqing, high-temperature steam sterilization technology has limitations. It can only be used to dispose of infectious and damaged wastes, but not to dispose drug-induced, pathological and chemical wastes. There are also strict requirements for the separate collection of medical wastes [7]. 
Second, after the high temperature incineration changed into high-temperature steam, medical and health institutions must entrust at least three disposal units to dispose of medical wastes, thus the environmental management cost of medical wastes and disposal charge will increase. Chemical and drug-induced medical wastes cannot be disposed of by the corresponding hazardous waste business units, and the pathological wastes cannot be disposed of safely at all.

\section{Suggestions}

For an early realization of all centralized and harmless disposal of medical wastes in Chongqing, combined with actual conditions, the pollution prevention and control of medical wastes is enhanced, and the disease transmission of medical wastes is reduced from the perspectives of perfecting charging system, standardizing separate collection of medical wastes, establishing an information management system, and perfecting the environmental management means of medical wastes [8-9]. The suggestions are as follows:

Standardizing Separate Collection of Medical Wastes. Medical and health institutions must standardize the separate collection of medical wastes, as well as containers and wrappings based on the requirements of national codes. It is forbidden to hold medical wastes in domestic garbage bags, waste paper boxes, etc., according to national hazardous waste exemption management requirements. In remote mountainous areas, township medical and health institutions must establish concentrated transfer warehouses for medical wastes, small medical and health institutions transfer the medical wastes to concentrated transfer warehouse by themselves, and then the disposal units of medical wastes conduct concentrated disposal, so as to reduce the concentrated collection-transportation cost of medical wastes, improve the concentrated collection-transportation rate of medical wastes, and decrease the risk of disease transmission [10].

Establishing an Information Management System of Medical Wastes. An information management system of medical wastes must be established, involving cloud technology, mobile terminals, and other internet information technologies and equipment, while an electronic manifest of medical wastes is created, and data information managements such as the production, transfer, and the disposal of medical wastes must be achieved by means of large data analysis, which provides a technological basis for the decision-making of medical waste pollution prevention and control.

Perfecting Environmental Management Means of Medical Wastes. The overall layout for the centralized disposal facilities for medical wastes must meet the current and future concentrated disposal requirements of medical wastes, and consider the pollution prevention and control of medical wastes and environmental management cost. The Department of Health and the Environmental Protection Department must actively guide and supervise medical and health institutions to standardize the separate collection and disposal of medical wastes, so as to adapt to the changes of disposal technology of medical wastes. The business scope of hazardous waste business units provided with the incineration disposal of medical wastes must be adjusted, and the business unit must be approved to dispose of chemical and drug medical wastes; business licenses of hazardous waste for disposal of pathological medical waste crematoriums must be exempted; the business category of disposal units of medical waste adopting high-temperature steam disinfection technology must be checked; and restrictions on the disposal of infectious and damaged wastes and miscollections of other categories of medical wastes must be transferred to corresponding disposal units, and then disposed of in a timely manner. In this way, the mismatching between changes of concentrated disposal technology of medical wastes and requirements of pollution prevention and control of medical wastes can be resolved, and the existing business licenses of hazardous waste during separate collection and disposal of medical wastes can be standardized. 


\section{References}

[1] Health and Family Planning Commisson of Chongqing. Analysis Report of Health Statistics Annual Report of Chongqing in 2015 [R]. Chongqing: Official Website of Chongqing Health Information Center, 2016, 05.

[2] Health and Family Planning Commisson of Chongqing. A Statistical Communique on the Development of Health (Family Planning) Business in Chongqing in 2011-2014 [R]. Chongqing: Official Website of Health and Family Planning Commisson of Chongqing, 2012-2015, 04.

[3] Chongqing Environmental Protection Bureau. Information on Pollution Prevention and Control of Solid Waste in Chongqing in 2011-2015 [R]. Chongqing: Governmental Public Information Service Network of Chongqing Municipal Environmental Protection Bureau, 2012-2016, 06.

[4] J Chen, T Chen, Q Wang et al. Research on Emission Level of Dioxin in Incineration Disposal of Chinese Dangerous Wastes and Medical Wastes [J]. Acta Scientiae Circumstantiae, 2014, 34(4): 973-979.

[5] SW Yang, XQ He, JC Chen et al. Research on Disposal Status and Countermeasure of Medical Wastes in Chongqing [J]. Environmental Science and Management, 2015, 40 (12): 81-84.

[6] JX Wang and JX Niu. Research on Improvement of Disposal Technology of Medical Wastes and Operation Effect [J]. Environmental Science and Management, 2013, 38(7): 65-68.

[7] XL Zhou. Problems and Countermeasures Existing in Management of Medical Wastes in Henan. Guangdong Chemical Industry, 2014, 41 (17): 111-123.

[8] Q Wang, SL Wu, YF Zhang et al. Policy Thinking on Perfecting the Harmless Disposal and Management of Medical Wastes in China [J]. Chinese Journal of Environmental Management, 2013, 2: 49-53.

[9] JX Chen. Investigation and Analysis of Management Status of Medical Wastes of Medical Institutions in Dandong [J]. Jiangsu Healthcare Administration, 2015, 26(2): 66-68.

[10]HJ Song. Status Analysis of Medical Waste Treatment and Countermeasure Research in Zhengzhou [J]. Environmental Sanitary Engineering, 2014, 22 (2): 56-58. 